\title{
VERBA BERPREPOSISI DALAM BAHASA INDONESIA
}

\author{
oleh Suhardi \\ FBS Universitas Negeri Yogyakarta
}

\begin{abstract}
A verb with a preposition here refers to a verb with a preposition following it in use. So a verb to be used that way differs from a verb phrase; the latter consists of one main element with at least one other element added to it while the former consists of a verb and a preposition with neither being a main element nor an added element. Therefore, a verb phrase is endocentric in nature while a verb with a preposition is exocentric in nature.

A verb with a preposition can be with or without an affix. The affixes commonly used in such verbs are, among others, ber-, ber-an, and ber-kan (as used in, for example, berfungsi sebagai, berkenaan dengan, and berdasarkan atas); di-, di-kan, di-i, and diper-kan (as used in, for example, dibagi atas, diarahkan kepada, diikuti oleh, and dipergunakan sebagai); me(N)- (as used in, for example, mengarah pada and mengacu ke); and ter-and ter-kan (as used in, for example, tergantung pada, terdiri atas, and terbedakan dari). Meanwhile, the prepositions used with such verbs can be (1) single prepositions without affixes (such as, di, ke, dari, pada, atas, and dengan) or with affixes (such as, sebagai, terhadap, menjadi, and mengenai) or (2) combined prepositions used side by side (such as, kepada, daripada, ke dalam, and di dalam) or in pairs (such as, antara dan ...; antara dengan ...; and dari hingga ...). In addition, the presence of some prepositions after some verbs (as that in, for example, berkembang menjadi and berdomisili di) is obligatory while that of some other prepositions after some other verbs (as that in, for example, berbicara tentang, dihadiri oleh, and terdiri atas/ dari) is optional.
\end{abstract}

Keywords: verb, preposition, verb with preposition

\section{A. Pendahuluan}

Verba berpreposisi (VBp) merupakan bentuk verba yang diikuti preposisi. VBp tersebut terdiri atas unsur verba sebagai poros (axis) dan unsur preposisi sebagai direktor (director). Oleh sebab itu, VBp bersifat 
eksosentris direktif.

Perilaku VBp dalam bahasa Indonesia (BI) berbeda dengan VBp dalam bahasa lain, seperti bahasa Inggris. Misalnya, VBp dalam kalimat Kehidupan anak itu bergatung pada kedua orang tuanya, preposisi pada tidak dapat diletakkan di akhir kalimat sehingga bentuk kalimat *Kehidupan anak itu bergantung kedua orang tuanya pada merupakan kalimat yang tidak berterima, baik secara semantis maupun sintaktis. Berbeda halnya dengan VBp dalam bahasa Inggris, seperti yang digambarkan oleh Leech dan Svartvik (1987: 265) bahwa preposisi up pada kalimat They called up all young men dapat diletakkan di akhir kalimat sehingga kalimat tersebut dapat diungkapkan menjadi They called all young men up.

Beberapa ahli bahasa, seperti Kridalaksana (1986), Sugono dan Indiyastini (1994), dan Alwi et al. (1998) telah mengemukakan persoalan VBp tersebut secara singkat. Dalam pembicaraan tersebut belum terungkap berbagai hal yang terkait dengan VBp, antara lain bentuk verba yang diikuti preposisi, bentuk preposisi yang menyertai verba, dan keberadaan preposisi setelah verba. Oleh sebab itu, melalui tulisan ini, persoalan tersebut perlu dikaji lebih lanjut.

\section{B. Perihal Verba dan Preposisi dalam BI}

\section{Perihal Verba}

Yang dimaksud verba di sini adalah salah satu kategori kata yang mengisi P pada kalimat verbal. Verba dapat dikenali melalui beberapa hal, antara lain bentuk, fungsi, sintaksis, dan semantik. Dilihat dari segi bentuk, Sugono dan Indiyastini (1994: 19-21) mengelompokkan verba atas dua jenis, yakni verba tanpa tanda bentuk (verba tidak berafiks) dan verba dengan tanda bentuk (verba berafiks). Verba jenis pertama dapat berupa kata tunggal (misalnya, datang, pergi, duduk), kata ulang misalnya, duduk-duduk, lari-lari, makan-makan), kombinasi kata (misalnya, bunuh diri, pulang pergi, cuci mata). Sementara itu, verba jenis kedua pada umumnya berprefiks me(N)-, ber-, ter-, di- (misalnya, menulis, berdagang, tersumbat, diambil), dapat pula berafiks kombinasi, 
seperti memper-kan, memper-i, member-kan, me(N)-i, me(N)-kan, ter-i, ter-kan, di-i, di-kan, diper-i, diper-kan (misalnya, memperdengarkan, memperbaiki, memberhentikan, diperbolehkan), dan dapat juga berkonfiks ke-an, ber-an (misalnya, kehabisan, bersentuhan).

Dilihat dari segi fungsi, verba memiliki fungsi utama sebagai $\mathrm{P}$ dalam kalimat atau klausa (lihat: Schachter dalam Shopen (Ed.), 1996: 9 dan Alwi et al., 1998: 87). Di samping itu, verba dapat pula berfungsi sebagai atribut. Misalnya, kalimat Ia akan mendaftar ujian terbuka, verba mendaftar berfungsi sebagai $\mathrm{P}$ (inti P), sedangkan verba terbuka berfungsi sebagai atribut terhadap nomina ujian. Hubungan antara unsur inti dan atribut pada frasa ujian terbuka tersebut bukan saja ditunjukkan oleh struktur nomina dan verba, melainkan sesungguhnya ada unsur lain, seperti kata yang atau yang sejenis yang berada di antaranya. Jika unsur yang menjembatani itu dieksplisitkan, frasa tersebut akan berupa ujian yang (bersifat) terbuka.

Di samping verba itu berfungsi utama sebagai $\mathrm{P}$ dan dapat pula berfungsi sebagai atribut, Sugono dan Indiyastini (1994: 29-30) berpendapat bahwa verba dapat juga berfungsi sebagai S, misalnya kalimat Memarahi murid di depan teman-temannya itu, tidak bijaksana. Menurut hemat saya, pandangan tersebut perlu dipertimbangkan lebih lanjut karena ada penafsiran lain, yakni kata memarahi pada kalimat tersebut merupakan atribut terhadap kata lain yang menjadi inti, tetapi tidak dieksplisitkan, seperti kata nomina tindakan atau yang sejenis. Dengan demikian, jika dinyatakan secara eksplisit, kalimat tersebut berupa Tindakan memarahi murid di depan teman-temannya itu tidak bijaksana. Jadi, sesungguhnya S pada kalimat tersebut adalah nomina atau frasa nominal, bukan verba atau frasa verbal.

Dilihat dari segi semantik, dapat dikenal tiga macam verba,yakni verba perbuatan, verba proses, dan verba keadaan (lihat: Sugono dan Indiyastini, 1994: 32; Schachter dalam Shopen (Ed.), 1996: 9; dan Alwi et al., 1998: 87). Verba perbuatan adalah verba yang mengandung makna perbuatan atau tindakan dan biasanya dapat digunakan untuk menjawab pertanyaan "Apa yang dilakukan oleh subjek?” Di samping itu, verba

DIKSI Vol.12, No.2, Juli 2005 
perbuatan ini biasanya dapat digunakan untuk membuat kalimat perintah. Contoh kalimat (la) berikut verba yang menduduki fungsi P bermakna 'perbuatan dan kalimat (lb) merupakan kalimat perintah yang dibentuk atas dasar kalimat (I a).

(1) a. Polisi memukul penjahat itu. (Verba bermakna 'perbuatan'

b. Pukullah! (Kalimat perintah)

Apabila sufiks kan atau $i$ ditambahkan pada verba perbuatan, akan terjadi penambahan makna terhadap verba yang bersangkutan. Misalnya, jika verba perbuatan memukul ditambah sufiks $i$ menjadi memukuli, verba memukuli tersebut akan bermakna 'perbuatan/tindakan yang dilakukan berulang-ulang'.

Verba proses adalah verba yang mengandung makna perubahan dan suatu keadaan ke keadaan yang lain dan biasanya dapat digunakan untuk menjawab pertanyaan "Apa yang sedang terjadi pada subjek? (Alwi et al., 1988: 88). Dalam hal ini perlu dicatat bahwa tidak semua verba proses dapat digunakan untuk membuat kalimat perintah, seperti pada verba perbuatan. Verba pada contoh kalimat (2a dan 3a) berikut adalah verba proses. Namun, verba pada kalimat (2a) dapat digunakan untuk membuat kalimat perintah, seperti pada contoh (2b), sedangkan verba pada kalimat (3a) tidak dapat digunakan untuk membuat kalimat perintah karena subjeknya tidak menunjuk persona kedua, seperti tampak pada contoh $(3 b)$.

(2) a. Para pemain meluncur ke bawah. (Verba proses)

b. Meluncurlah ke bawah! (Kalimat perintah)

(3) a. Virus SARS menyebar ke berbagai belahan dunia. (Verba proses)

b. *Menyebarlah ke berbagai belahan dunia! (Tidak berterima sebagai perintah)

Verba keadaan adalah verba yang mengandung makna keadaan dan dapat digunakan untuk menjawab pertanyaan "Bagaimana subjek?", tetapi tidak dapat dipakai untuk menjawab pertanyaan "Apa yang dilakukan subjek atau apa yang terjadi pada subjek? Selain itu, verba 
keadaan ini tidak dapat digunakan untuk membuat kalimat perintah. Misalnya, verba keadaan pada kalimat (4a) berikut tidak dapat dipakai untuk membentuk perintah, seperti tampak pada kalimat (4b), kecuali hal itu sebagai bentuk kalimat lain, bukan kalimat perintah, sehingga lah tidak lagi sebagai penunjuk perintah, tetapi sebagai partikel penegas.

(4) a. HP dia hilang beberapa hari yang lalu. (Verba keadaan)

b. *Hilanglah beberapa hari yang lalu! (Tidak berterima sebagai perintah)

Apabila dilihat dari segi hubungan verba dengan argumen, dapat dikenal empat jenis verba, yakni verba aktif, verba pasif, verba antiaktif, dan verba anti-pasif (lihat: Kridalaksana, 1985: 54-56; dan 1986: 51-52). Verba digolongkan verba aktif apabila $\mathrm{S}$ pada kalimat verbal yang bersangkutan berperan pelaku atau penanggap dan dikategorikan verba pasif jika $\mathrm{S}$ pada kalimat verbal yang bersangkutan berperan penderita atau hasil. Verba aktif biasanya ditandai oleh penggunaan afiks $m e N$-, afiks meN- yang berkombinasi dengan afiks kan, afiks ber-/berkan, konfiks ber-an, atau tanpa afiks, sedangkan verba pasif biasanya ditandai penggunaan afiks $d i$-, afiks $d i$ - yang berkombinasi dengan afiks kan, atau afiks lain, afiks ter-, afiks ter-yang berkombinasi dengan kan atau konfiks ke-an, atau persona + verba tanprefiks. Kalimat pasif yang ditandai oleh persona + verba tanprefiks dapat diberikan contoh kalimat nomor (5) berikut ini.

(5) Kredit itu telah saya bayar sejak bulan lalu.

S P (V-PsfPrs) K

Verba anti-aktif (ergatif) adalah verba pasif yang tidak dapat diubah menjadi verba aktif dan subjeknya berperan pengalam (experiences), sedangkan verba anti-pasif yaitu verba aktif yang tidak dapat diubah menjadi verba pasif. Predikat pada contoh kalimat (11 a dan b) berikut berupa verba anti-aktif, sedangkan pada contoh kalimat (12a dan b) berikut berupa verba anti-pasif.

(6) a. Di tempat itulah Murni kecopetan. K $\quad \mathrm{S} \quad \mathrm{P}$ (V anti-aktif) 
b. Ban mobil sebelah kanan terantuk pagar pembatas. $\mathrm{S}$

$\mathrm{P}(\mathrm{V}$ anti-aktif) Pel

(7)
a. Mereka
$\underline{\text { haus }}$
$\mathrm{S} \quad \mathrm{P}$ (V anti-pasif)
akan kasih sayang.
Pel

b. Saat ini mereka sedang bertanam padi.

$\mathrm{K} \quad \mathrm{S} \quad \mathrm{P}$ (V anti-pasif) Pel

Di samping hal-hal di atas, secara sintaktis ciri lain verba adalah tidak dapat digabung atau didahului oleh kata penyangatan, seperti kata paling, sangat. Misalnya, verba duduk dan dihadang tidak dapat didahului oleh kata penyangatan menjadi *sangat duduk, *paling duduk, *sangat dihadang, *paling dihadang.

\section{Perihal Preposisi}

Dalam BI istilah preposisi disebut pula kata depan karena secara sintaktis, preposisi selalu digunakan sebelum/di depan kata atau frasa lain yang biasanya berkategori nomina, adjektiva, atau adverbia sehingga membentuk konstruksi eksosentris derektif yang berupa frasa preposisional. Dalam konstruksi sintaksis, preposisi tidak pernah dapat berdiri sendiri, tanpa kata atau frasa lain yang menyertainya. Di samping itu, preposisi hanya bertugas menghubungkan makna antara unsur yang mendahului dan unsur yang mengikutinya. Oleh karena itu, preposisi merupakan salah satu bentuk kata tugas, selain konjungsi, interjeksi, artikula, dan partikel penegas (lihat: Alwi et al., 1998: 288).

Dalam bahasa-bahasa flektif, misalnya bahasa Inggris, preposisi (seperti, to, of, on, with) termasuk dalam kategori partikel, yaitu segolongan kata yang tidak dapat mengalami infleksi. Sehubungan dengan hal ini, Ramlan (1980: 14) menegaskan bahwa partikel (termasuk preposisi) merupakan segolongan kata yang tidak dapat berdiri sendiri sebagai subjek atau predikat. Oleh karena preposisi

sebagai salah satu bentuk partikel yang berfungsi menghubungkan kata atau frasa sehingga terbentuk konstruksi eksosentrik direktif preposisional, Kridalaksana et al. (1985: 74) menyebutkan bahwa preposisi merupakan partikel yang berfungsi menghubungkan kata atau frasa sehingga berbentuk frasa eksosentris. 
Dalam frasa eksosentris tersebut terdapat unsur preposisi yang berfungsi sebagai pemarkah (penanda) dan unsur kata atau frasa lain yang berfungsi sebagai termarkah (petanda). Misalnya, frasa di Lapangan Gasibo, preposisi di sebagai pemarkah dan frasa Lapangan Gasibo sebagai termarkah. Preposisi $d i$ tersebut tidak mungkin dapat berdiri sendiri tanpa disertai frasa Lapangan Gasibu. Demikian pula, preposisi $d i$ dan yang sejenis tidak mungkin berdiri sendiri untuk menduduki fungsi sintaksis tertentu, seperti S, P, O, Pel, atau K. Atas dasar beberapa konsep preposisi di atas, preposisi sebagai salah satu bentuk partikel memiliki karakteristik tertentu, yakni (1) preposisi sebagai salah satu wujud partikel, (2) preposisi tidak dapat berdiri sendiri tanpa disertai kata atau frasa lain, (3) preposisi tidak dapat berdiri sendiri menduduki fungsi sintaksis S, P, O, Pel, atau K, (4) preposisi berfungsi untuk membentuk frasa eksosentris direktif preposisional (frasa preposisional), dan (5) preposisi sebagai pemarkah pertalian makna antara unsur yang mendahului dan unsur yang mengikutinya.

Dalam pemakaian bahasa sering dijumpai sebuah kata dalam konteks tertentu sebagai preposisi dan dalam konteks yang lain sebagai konjungsi, bahkan dapat pula berkategori lain (bukan partikel). Misalnya,

(8) a. Toni bersedia karena bujukan saya. (karena sebagai preposisi)

b. Toni bersedia karena orang tuanya datang. (karena sebagai konjungsi

Kata karena pada kalimat (8a) merupakan preposisi. Kata karena sebagai direktor dan frasa nomina bujukan saya sebagai poros (axis) sehingga terbentuk frasa preposisional karena bujukan saya. Berbeda halnya dengan kalimat (8b) kata karena merupakan konjungsi (penghubung) subordinatif. Data karena pada kalimat (8b) ini bertugas menghubungkan klausa matriks Toni bersedia dengan klausa bawahan orang tuanya datang sehingga terbentuk sebuah kalimat majemuk bertingkat (subordinatif) nomor (8b) tersebut. 
Dilihat dari segi bentuk, preposisi dapat dikelompokkan atas dua jenis, yakni preposisi tunggal dan preposisi gabungan (Alwi et al., 1998: 288-292). Preposisi tunggal merupakan preposisi yang hanya berupa satu kata, baik yang berbentuk kata dasar, seperti di, ke, dari, pada, maupun berbentuk kata berafiks, seperti selama, sepanjang, selain, mengenai, menurut. Sementara itu, preposisi gabungan merupakan preposisi yang terdiri atas dua kata, baik berbentuk dua kata yang berdampingan, seperti kepada, daripada, oleh karena, sampai dengan, maupun berbentuk dua kata yang berpasangan (berkorelasi), seperti antara dengan dari sampai sejak hingga .... Hal tersebut dapat diberikan contoh dalam kalimat (9a dan b) dan (10a dan b) berikut.

(9) a. Mereka berasal dari Kalimantan Barat.

b. Para mahasiswa berdiskusi mengenai pelaksanaan reformasi.

(10) a. Petinju Irak itu lebih tinggi daripada petinju Indonesia.

b. Antara buruh dan majikan belum ada kesepahaman.

Preposisi dari dan mengenai pada kalimat (9a dan b) masingmasing sebagai preposisi tunggal, sedangkan preposisi daripada pada kalimat (10a) sebagai preposisi gabungan yang berdampingan dan preposisi antara...dan... pada kalimat (10b) merupakan preposisi gabungan berpasangan.

Selain kedua bentuk preposisi tersebut, dalam pemakaian BI sering terjadi sebuah preposisi yang bergabung dengan dua nomina, dengan syarat nomina pertama hams bersifat lokatif (lihat: Alwi et al., 1998: 291; Kridalaksana et al., 1985: 74; dan Kridalaksana, 1986: 9394). Dengan demikian, dapat ditemukan bentuk frasa preposisional, seperti di sekitar rumah, ke dalam kantor dari samping pasar.

Pengelompokan preposisi atas dua jenis dikemukakan pula oleh Quirk et al. (1989: 300-301) dengan istilah yang berbeda, yakni preposisi sederhana (simple preposition) dan preposisi kompleks (complex preposition). Namun, substansinya sedikit berbeda, yakni pada jenis preposisi tunggal yang dikemukakan Alwi at. al. dapat berupa kata dasar dan kata berafiks, sedangkan pada jenis preposisi sederhana yang 
dikemukakan Quirk et al. tidak disebutkan adanya bentuk preposisi berafiks. Sementara itu, substansi jenis preposisi gabungan sama dengan jenis preposisi kompleks.

Selain kedua pengelompokan preposisi di atas, Kridalaksana at al. (1985: 74) dan Kridalaksana (1986: 93-95) mengelompokkan preposisi atas tiga jenis, yakni preposisi dasar, preposisi turunan, dan preposisi yang berasal dari kategori lain. Preposisi dasar yaitu preposisi yang tidak dapat mengalami proses morfologis, seperti derivasi, misalnya kata $d i$, ke, dari, bak, pada, demi. Preposisi turunan yaitu preposisi yang telah mengalami afiksasi, seperti selama, bagaikan, mengenai dan yang telah mengalami proses penggabungan, seperti kepada, daripada, oleh karena, sejak ... hingga ..., dari... sampai ..., antara ... dengan ..., di atas ... dari bawah ..., ke depan ...Ketiga contoh preposisi gabungan yang terakhir tersebut (di atas ..., ke depan ..., dari bawah ...) menghendaki persyaratan khusus, yakni nomina pertama yang langsung mengikuti preposisi harus bersifat lokatif, misalnya frasa preposisional di atas meja, ke depan pintu, dari bawah jembatan.

Secara substansial, pengelompokan preposisi yang dikemukakan oleh Kridalaksana tersebut kurang lebih sama dengan pengelompokan preposisi yang dikemukakan oleh Alwi et al.. Untuk itu, dalam tulisan ini konsep preposisi yang dikemukakan Alwi et al. (1998) dalam Tatata Bahasa Baku Bahasa Indonesia itulah yang digunakan, sedang konsep yang lain dipakai sebagai bahan pertimbangan dan pengayaan.

Atas dasar keberadaannya dalam konstruksi sintaksis, preposisi dapat dikelompokkan menjadi tiga, yakni preposisi yang berada sebelum kata atau frasa lain (preposed preposition), preposisi yang berada pada akhir/setelah konstruksi sintaksis lain (postponed preposition), dan preposisi yang berada sebelum dan setelah kata atau frasa lain secara berpasangan (lihat: Murphy, 1987; Thomson dan Martinet, 1987). Jenis pertama telah lazim ada dalam berbagai bahasa, termasuk BI, sedangkan jenis kedua belum tentu ada dalam semua bahasa. Jenis preposisi yang berada pada akhir atau setelah konstruksi sintaksis lain banyak ditemui dalam bahasa Inggris atau bahasa lain yang sejenis. Misalnya kata at, 
to, of pada kalimat (11) berikut.

(11) a. Which house did you leave it at?

b. He's worth listening to.

c. What I'm convinced $\boldsymbol{o f}$ is that the world's population . .

\section{Bentuk Verba Berpreposisi}

1. Bentuk Verba yang Diikuti Preposisi

Bentuk verba yang diikuti preposisi ini dikelompokkan atas dua jenis, yaitu bentuk verba tanafiks + preposisi (Vtaf + Prep) dan bentuk verba berafiks + preposisi (Vbaf+ Prep).

\section{a. Bentuk Verba Tanafiks + Preposisi}

Bentuk verba tanafiks + preposisi adalah verba yang tidak berafiks yang diikuti preposisi. Bentuk verba ini dapat muncul tanpa pendamping kiri atau kanan, tetapi dapat pula berpendamping kiri atau kanan. Pendamping kiri verba dapat berupa kata aspek (misalnya, telah, sudah, sedang, lagi, akan), modalitas (misalnya, mungkin, barangkali, tentu, pasti), negasi (misalnya, tidak, tak, belum), partikel pembatas (misalnya, hanya, cuma, sekedar), sedangkan pendamping kanan verba dapat berupa kata penegas (misalnya, juga, pula, kembali) atau preposisi (misalnya, di, pada, tentang, mengenai).

Dari hasil pengamatan yang dilakukan, bentuk verba tanafiks yang diikuti preposisi (VTaf + Prep) tersebut tidak banyak ditemukan. Berikut ini disajikan beberapa contoh bentuk VTaf+ Prep.

(12) Keterampilan siswa pada umumnya ada dalam kategori intermediate dan elementary.

(13) Mereka tinggal di sejumlah kota dan desa.

(14) Beberapa peserta lomba datang dari luar provinsi.

(15) Kita akan bicara tentang kualifikasi, gaji, dan sebagainya.

(16) Pilihan tentu jatuh pada bahasa pemersatu.

(17) Binatang buruannya hampir masuk ke dalam perangkap yang telah dipasang beberapa hari sebelumnya. 
Secara sintaktis, preposisi dalam, di, dan dari pada kalimat (12-14) tersebut berkaitan erat dengan nomina atau frasa nominal yang menyertainya. Namun, secara semantis ketiga preposisi tersebut berkaitan erat dengan verba yang mendahuluinya. Oleh sebab itu, ketiga preposisi tersebut wajib hadir. Apabila preposisi setelah verba pada kalimat (12-14) tersebut ditiadakan, kalimat yang dihasilkannya tidak gramatis dan tidak berterima, seperti tampak pada kalimat (12a - 14a) berikut.

(12a) *Keterampilan siswa pada umumnya ada $\theta$ kategori intermediate dan elementary.

(13a) * Mereka tinggal $\theta$ sejumlah kota dan desa.

(14a) *Beberapa peserta lomba datang $\theta$ luar provinsi.

Berbeda halnya dengan ketiga kalimat tersebut, preposisi tentang, pada, dan ke dalam setelah verba pada kalimat (15-17) tersebut masing-masing bersifat tidak wajib. Artinya, preposisi setelah verba pada ketiga kalimat tersebut berpotensi tidak dihadirkan dalam kalimat. Ketidakhadiran preposisi-preposisi tersebut setelah verba tidak mengurangi nilai kegramatikalan kalimat. Dengan kata lain, walaupun preposisi setelah verba pada kalimat (15-17) tersebut tidak hadir, ketiga kalimat tersebut tetap berterima, baik secara semantis maupun sintaktis, seperti tampak pada kalimat (15a-17a) berikut.

(1 5a) Kita bicara $\theta$ kualifikasi, gaj dan sebagainya.

(16a) Pilihan jatuh $\theta$ bahasa pemersatu.

(17a) Binatang buruannya masuk $\theta$ perangkap yang telah dipasang beberapa hari sebelumnya.

Secara sintaktis, preposisi tentang, pada, dan ke dalam pada kalimat (15), (16), dan (17) tidak memiliki keterikatan dengan nomina atau frasa nominnal yang menyertai, dan juga tidak memiliki keterikatan dengan verba yang mendahului. Namur, secara semantis, ketiga preposisi tersebut masing-masing memiliki keterikatan dengan verba yang mendahului. Oleh sebab itulah, ketiga preposisi tersebut bersifat manasuka sehingga berpotensi tidak hadir dalam kalimat dan

DIKSI Vol.12, No.2, Juli 2005 
ketidakhadirannya setelah verba tidak mengurangi nilai kegramatikalan kalimat yang bersangkutan, seperti tampak pada kalimat $(15 \mathrm{a}-17 \mathrm{a}) \mathrm{di}$ atas.

Perlu ditambahkan di sini bahwa tidak setiap nomina atau frasa nominal yang menyertai VTaf + Prep merupakan Pel, tetapi berkemungkinan sebagai keterangan kalimat (K). Satuan bahasa yang menyertai VTaf + Prep bersama dengan preposisi tersebut membentuk satuan bahasa yang berfungsi sebagai $\mathrm{K}$. Hal ini dapat ditunjukkan pada contoh kalimat (18) dan (19) berikut.

(18) Para artis bicara di depan penggemarnya.

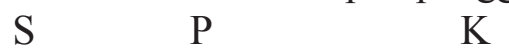

(19) Para artis masuk dari pintu samping.

$\mathrm{S} \quad \mathrm{P} \quad \mathrm{K}$

Satuan bahasa di depan penggemarnya pada kalimat (18) dan dari pintu samping pada kalimat (19) masing-masing sebagai K yang berposisi di akhir kalimat. Oleh karena sebagai $\mathrm{K}$, kedua satuan bahasa tersebut bisa ditiadakan dan memiliki kemungkinan dipindah posisinya di awal kalimat, di antara S dan $\mathrm{P}$, bahkan di antara $\mathrm{P}$ dan $\mathrm{K}$ tersebut dapat ditempati Pel. Oleh sebab itu, kalimat (18) dan (19) tersebut masingmasing dapat divariasikan sebagai kalimat (18a,b,c,d) dan (19a,b,c,d) berikut.

(18) a. Para artis bicara.

$$
\mathrm{S} \quad \mathrm{P}
$$

b. Di depan penggemarnya para artis bicara.

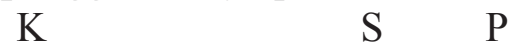

c. Para artis di depan penggemarnya bicara.

$\begin{array}{lll}\mathrm{S} & \mathrm{K} & \mathrm{P}\end{array}$

d. Para artis bicara (tentang) perkembangan seni di depan $\mathrm{S} \quad \mathrm{P} \quad$ Pel $\quad \mathrm{K}$ penggemarnya. 
(19) a. Para artis masuk.

$\mathrm{S} \quad \mathrm{P}$

b. Dari pintu samping para artis masuk.

K

$\mathrm{S} \quad \mathrm{P}$

c. Para artis dari pintu samping masuk.

S $\mathrm{K} \quad \mathrm{P}$

d. Para artis masuk (ke) studio rekaman dari pintu samping. $\begin{array}{llll}\mathrm{S} & \mathrm{P} & \mathrm{P} & \mathrm{K}\end{array}$

Keberadaan preposisi tentang pada tentang perkembangan seni dalam kalimat (18d) dan preposisi ke pada ke studio rekaman dalam kalimat (19d) bersifat manasuka, sedangkan preposisi di pada di depan penggemarnya dalam kalimat $(18 \mathrm{~b}, \mathrm{c})$ dan preposisi dari pada dari pintu samping dalam kalimat $(19 \mathrm{~b}, \mathrm{c})$ bersifat wajib yang secara bersama-sama membentuk konstruksi eksosentris direktifpreposisional. Sementara itu, apabila Pel tentang perkembangan seni pada kalimat (18d) dan Pel ke studio rekaman pada kalimat (19d) ditransposisikan ke belakang $\mathrm{K}$, preposisi tentang dan ke tersebut menjadi bersifat wajib. Oleh sebab itu, struktur kalimat (18e) dan (19e) berikut dapat berterima, sedangkan struktur kalimat (18f) dan (19f) berikut meragukan, bahkan tak berterima.

(18) e. Para artis bicara di depan penggemarnya tentang perkembangan seni.

f. *Para artis bicara, di depan penggemarnya $\theta$ perkembangan seni.

(19) e. Para artis masuk dari pintu samping ke studio rekaman.

f. *Para artis masuk dari pintu samping $\theta$ studio rekaman.

Untuk kalimat (19f), apabila frasa studio rekaman sebagai atribut terhadap frasa pintu samping, kalimat tersebut dapat berterima sebagai kalimat tersendiri yang secara semantis berbeda dengan kalimat (19a) dan (19e). Namun, jika frasa studio rekaman tersebut sebagai Pel terhadap verba masuk, kalimat (190 tersebut tidak berterima, baik secara sintaktis

DIKSI Vol.12, No.2, Juli 2005 
maupun semantis.

Atas dasar deskripsi di atas, dapat diketahui bahwa bentuk VTaf + Prep yang disertai Pel ada dua tipe, yaitu VTaf + Prep wajib (seperti, ada dalam..., tinggal di ..., datang dari ..., jatuh pada/ke...), dan VTaf + Prep tidak wajib (seperti, bicara tentang ..., masuk ke/dalam ..., tahu akan/tentang ....).

\section{b. Bentuk Verba Berafiks + Preposisi}

Bentuk verba berafiks + preposisi (VBaf + Prep) adalah verba yang menggunakan afiks tertentu dan disertai preposisi. Afiks-afiks tertentu yang digunakan dalam VBaf + Prep tersebut, antara lain afiks ber-, ber-kan, di-, di-kan, di-i, diper-kan, me(N)-, ter-, ter-kan dan konfiks ber-an. VBaf yang menggunakan afiks-afiks tersebut tergolong verba intransitif. Seperti halnya bentuk VTaf, bentuk VBaf ini juga dapat berpendamping kiri atau kanan. Berikut ini akan dikemukakan hal ihwal VBaf+ Prep yang menggunakan afiks-afiks tersebut.

\section{1) Bentuk Verba Berafiks ber- + Preposisi}

Bentuk verba berafiks ber- + preposisi (Vbaf ber- + Prep) adalah verba yang menggunakan afiks ber- yang diikuti preposisi dan disertai Pel. Atas dasar hubungan keterikatan preposisi dengan verba yang mendahului, preposisi yang menyertai VBaf ber- ada preposisi yang bersifat wajib hadir dan ada preposisi yang bersifat tidak wajib hadir. Berikut ini disajikan contoh preposisi wajib yang menyertai VBaf ber-.

(20) Sebagian besar pengguna Indonet berdomisili di Jakarta.

(21) Dalam perspektif inilah logika telah berkembang menjadi matematika.

(22) Hal itu tentu berpengaruh terhadap perilaku bangsa.

(23) Kepercayaannya berdasar pada adat dan tradisi.

(24) Guru yang berprestasi berhak pula atas hadiah yang layak. 
Preposisi $d i$, menjadi, terhadap, pada, dan atas yang menyertai verba pada kalimat (20-24) masing-masing bersifat wajib. Setiap preposisi tersebut dapat divariasikan dengan preposisi lain yang relavan, tetapi hal itu tidak dapat ditiadakan. Ketidakhadiran setiap preposisi tersebut setelah verba akan mengurangi nilai kegramatikalan kalimat yang bersangkutan, bahkan kalimat yang bersangkutan tidak berterima.

Berlainan halnya dengan preposisi pada kalimat (22-26), preposisi pada, soal, dan sebagai pada kalimat (25-27) berikut masing- masing bersifat tidak wajib sehingga dapat ditiadakan atau tidak digunakan.

(25) Penerbitan P3B bertumpu (pada) proyek.

(26) Dia berbicara ( $\underline{\text { soal })}$ ) santet.

(27) Peralatan berfungsi ( $\underline{\text { sebagai }}$ ) sarana dalam kehidupan.

\section{2) Bentuk Verba Berafiks ber-kan / ber-an + Preposisi}

Bentuk verba berafiks ber-kan / ber-an + preposisi merupakan verba berafiks kombinasi ber-kan yang diikuti preposisi (VBaf ber -kan + Prep) dan verba berafiks konfiks ber-an yang diikuti preposisi (VBaf ber-an + Prep) Kalimat (28 dan 29) berikut merupakan contoh bentuk VBaf ber-kan + Prep yang disertai Pel, sedangkan kalimat (30 dan 31) merupakan contoh bentuk VBaf ber-an + Prep yang disertai Pei.

(28) Penegakan supermasi hukum berdasarkan pada keadilan.

(29) Pengkategorian ini berdasarkan atas gejala umum yang terjadi...

(30) Di satu sisi kita berhadapan dengan kenyataan

(31) Tinjauan terhadap bahasa daerah ini berkenaan dengan kedua macam fungsinya.

Dilihat dari nilai kebakuan penggunaan bahasa Indonesia, kehadiran preposisi pada setelah verba berdasarkan pada kalimat (28) dan preposisi atas setelah verba berdasarkan pada kalimat (29) tersebut tidak diperlukan karena makna preposisi pada dan atas pada kedua kalimat tersebut telah tercermin pada afiks kan dalam verba berdasarkan. Hal ini dapat dianalogikan dengan penggunaan ber-kan pada verba 
beristerikan, bertuliskan, bertatahkan, dan lain-lain. Bentuk-bentuk verba tersebut tidak perlu diikuti preposisi spa pun apabila setelah verba disertai satuan bahasa yang berfungsi Pel. Oleh sebab itu, kalimat (28) dan (29) di atas cukup dinyatakan tanpa menggunakan preposisi setelah verba, seperti tampak pada kalimat (28a) dan (29a) berikut.

(28a) Penegakan supermasi hukum berdasarkan $\theta$ keadilan.

(29a) Pengkategorian ini berdasarkan $\theta$ gejala-gejala umum yang terjadi. .

Berbeda halnya dengan kalimat (28) dan (29) tersebut, penggunaan preposisi dengan setelah verba berhadapan pada kalimat (30) dan preposisi dengan setelah verba berkenaan pada kalimat (31) justru bersifat wajib. Apabila preposisi dengan setelah verba pada kalimat (30) dan (31) ditiadakan, struktur kedua kalimat tersebut tidak berterima, paling tidak dalam ragam tulis. Oleh sebab itu, struktur kalimat (30a) dan (31 a) berikut tidak berterima.

(30a) *Di satu sisi kita berhadapan $\theta$ kenyataan

(31a) *Tinjauan terhadap bahasa daerah ini berkenaan $\theta$ kedua macam fungsinya.

\section{3) Bentuk Verba Berafiks di-/di-kan/di-i/diper-kan+ Preposisi}

Bentuk verba berafiks di- / di-kan / di-i / diper-kan + preposisi adalah verba yang menggunakan afiks di-, di-kan, di-i, atau diper-kan yang diikuti preposisi (VBaf di- / di-kan / di-i / diper-kan + Prep) dan disertai Pel. Berikut ini disajikan contohnya masing-masing dalam kalimat.

(32) Bahasa Bali tersebut dianggap sebagai Bahasa Bali Baku.

(33) Larutan dibagi menjadi dua bagian.

(34) Tindakan diarahkan kepada barang atau sesuatu

(35) Pengetahuan intuitif dipergunakan sebagai hipotesis.

(36) Setiap lambang unsur diikuti oleh suatu angka 
Preposisi sebagai setelah verba dianggap pada kalimat (32), menjadi setelah verba dibagi pada kalimat (33), kepada setelah verba diarahkan pada kalimat (34), sebagai setelah verba dipergunakan pada kalimat (35), dan preposisi oleh setelah verba diikuti pada kalimat (36) masing-masing bersifat tidak wajib. Artinya, preposisi-preposisi setelah etiap lambang unsur diikuti oleh suatu angka verba tersebut dapat ditiadakan. Dengan kata lain, setiap preposisi setelah verba pada kalimat (32-36) di atas dapat divariasikan dengan ketidakhadiran preposisi tersebut.

Setiap preposisi setelah verba pada kalimat (32-36) tersebut dapat dielipskan atau disubstitusi dengan preposisi lain yang relevan. Misalnya, preposisi sebagai pada kalimat (32) dapat disulih dengan menjadi, tetapi preposisi menjadi pada kalimat (33) tidak dapat disulih dengan sebagai karena perbedaan makna verba yang mendahului, yaitu verba dianggap pada kalimat (32) mengandung makna 'penyikapan; sedangkan verba dibagi pada kalimat (33) mengandung makna pemilahan/pengelompokan'. Preposisi sebagai pada kalimat (35) dapat disulih dengan menjadi atau untuk karena verba dipergunakan pada kalimat tersebut mengandung makna 'kegunaan', sementara itu preposisi sebagai pada kalimat (32) tidak dapat disulih dengan untuk karena verba yang mendahuluinya tidak mengandung makna kegunaan. Preposisi kepada pada kalimat (34) dapat disulih dengan pada, ke, atau terhadap, sedangkan preposisi oleh pada kalimat (36) tidak dapat disulih dengan preposisi lain, tetapi preposisi tersebut dapat dielipskan karena hal itu menunjuk makna 'pelaku'

\section{4) Bentuk Verbs Berafiks meN- + Preposisi}

Bentuk verba berafiks me(N)- + preposisi (VBaf $m e(N)-+$ Prep) merupakan verba berafiks $m e(N)$-yang diikuti preposisi dan disertai Pel atau K. Dari hasil pengamatan yang dilakukan, bentuk verba ini tidak banyak ditemukan karena pada umumnya verba berafiks me $(N)$ tergolong bentuk verba aktif transitif dan tidak disertai preposisi. Berikut ini disajikan contoh kalimat yang mengandung VBaf me(N)- + Prep yang disertai Pel.

DIKSI Vol.12, No.2, Juli 2005 
(37) Buku paket mengarah pada buku ajar.

(38) Petunjuk itu mengacu $\underline{\boldsymbol{k e}}$ sebuah ketentuan.

(39) Dia merasa sebagai pahlawan.

Kehadiran preposisi pada setelah verba mengarah pada kalimat (37) dan preposisi ke setelah verba mengacu pada kalimat (38) bersifat wajib, sedangkan preposisi sebagai setelah verba merasa pada kalimat (39) bersifat tidak wajib. Apabila preposisi pada pada kalimat (37) dan preposisi ke pada kalimat (38) ditiadakan, akan muncul dua kemungkinan. Pertama, kalimat yang dihasilkannya menjadi rusak dan tak berterima, seperti tampak pada kalimat (37a) di bawah. Kedua, kalimat yang dihasilkannya berubah atau bergeser sebagai kalimat baru, yaitu satuan bahasa yang langsung mengikuti verba tidak lagi berfungsi sebagai Pel, tetapi sebagai O, seperti tampak pada kalimat (38a) di bawah ini.

(37a) ?*Buku paket mengarah buku ajar. (?*Ak tr)

(38a) Petunjuk itu mengacu sebuah ketentuan. (Ak tr)

Struktur dan makna kalimat (37a) tersebut tampak meragukan, apalagi hal itu dikategorikan sebagai kalimat aktif transitif lebih meragukan karena kalimat tersebut tidak dapat dipasifkan. Jika pemasifan kalimat (37a) dipaksakan, akan terjadi kalimat yang tidak gramatikal dan tidak logis dari segi makna, seperti tampak pada kalimat (37b) di bawah. Hal ini berbeda dengan kalimat (38a) karena struktur dan makna kalimat ini dapat berterima, meskipun berbeda dengan kalimat (38). Kalimat (38) merupakan kalimat intransitif sehingga tidak dapat dipasifkan, sedangkan kalimat (38a) dapat dikategorikan sebagai kalimat aktif transitif sehingga berpotensi diubah menjadi kalimat pasif, seperti dapat ditunjukkan pada kalimat (38b) di bawah ini.

(37b) ?* Buku ajar diarah (oleh) buku paket. (*Psf)

(38b) Sebuah ketentuan diacu (oleh) petunjuk itu. (Psf)

Berlainan halnya dengan kalimat (30) dan (31) di depan, preposisi sebagai pada kalimat (39) dapat ditiadakan dan kata pahlawan yang 
berada langsung setelah verba merasa tetap berfungsi sebagai Pel. Oleh sebab itu, struktur kalimat (39a) berikut, baik secara sintaktis maupun semantis tetap berterima dan tidak berbeda dengan kalimat (39) di atas, sedangkan kalimat (39b) berlainan dengan kalimat (39), terutama makna keseluruhan kalimat.

(39) a. Dia merasa pahlawan.

b. ?*Sebagai pahlawan dirasa oleh dia.

Secara keseluruhan makna kalimat (39a) sama dengan kalimat (39) yaitu 'dia belum/bukan pahlawan', sedangkan dalam kalimat (39b) terkandung makna 'dia telah/sedang menjadi pahlawan'.

Preposisi pada setelah verba mengarah pada kalimat (37) dapat divariasikan dengan preposisi lain yang relevan, misalnya kepada dan ke, sedangkan preposisi ke setelah verba mengacu pada kalimat (38) dapat divariasikan dengan preposisi pada dan kepada. Demikian pula preposisi sebagai setelah verba merasa pada kalimat (39) dapat divariasikan dengan preposisi lain yang relevan, yaitu menjadi dan jadi. Oleh karena preposisi pada dan ke pada kalimat (37) dan (38) tersebut bersifat wajib, hal itu tidak dapat divariasikan dengan ketidakhadiran preposisi setelah verba. Sementara itu, preposisi sebagai pada kalimat (39) bersifat tidak wajib sehingga hal tersebut dapat divariasikan dengan ketidakhadiran preposisi setelah verba secara langsung.

Apabila setelah verba mengarah, mengacu, dan merasa pada kalimat (37-39) secara langsung diikuti fungsi sintaksis $\mathrm{K}$, preposisi pada, ke, dan sebagai pada ketiga kalimat tersebut menjadi wajib hadir sebelum Pel. Hal ini dapat ditunjukkan pada struktur kalimat (37c-39c) berikut.

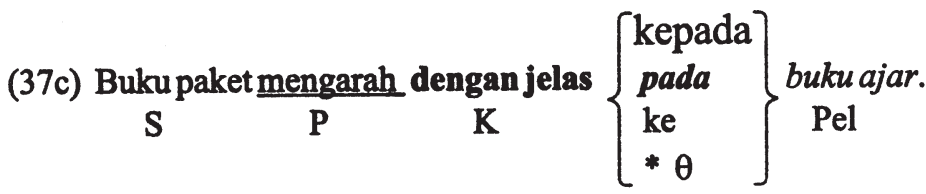

DIKSI Vol.12, No.2, Juli 2005 


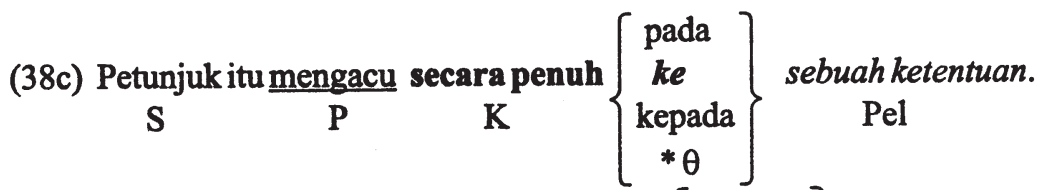

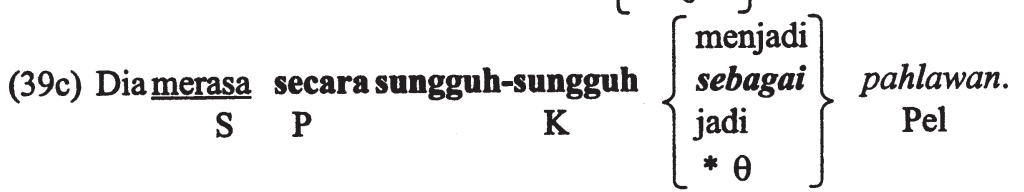

Selain itu, dalam pemakaian bahasa Indonesia sering pula dijumpai bentuk VBaf meN-, meN-kan, meN-i, memper-kan, memper-i, dan member-kan yang diikuti preposisi, tetapi satuan bahasa yang menyertainya bukan Pel, melainkan K. Misalnya, kalimat (40-42) bertikut, preposisi bersama dengan satuan bahasa setelah verba membentuk fungsi sintaksis K.

(40) Para siswa mengambil di almari ini buku bacaan baru.

$$
\mathrm{S} \quad \mathrm{P}(\mathrm{Vtr}) \quad \mathrm{K}
$$

(40) Direktur mengumumkan kepada mahasiswa peraturan herregistrasi.

$$
\begin{array}{llll}
\mathrm{S} & \mathrm{P}(\mathrm{Vtr}) & \mathrm{K} & \mathrm{O}
\end{array}
$$

(40) Sopir itu sedang memperbaiki di tepi jalan mesin mobilnya.
$\mathrm{S}$
$\mathrm{P}(\mathrm{Vtr})$
$\mathrm{K}$
$\mathrm{O}$

Apabila dikembalikan pada susunan yang runtut, seharusnya $\mathrm{K}$ pada kalimat (40-42) tersebut berada setelah O sehingga strukturnya menjadi SPOK.

\section{5) Bentuk Verba Berafiks ter-/ter-kan + Preposisi}

Bentuk verba berafiks ter- / ter-kan + preposisi (VBaf ter- / ter-kan + Prep) merupakan verba berafiks ter- atau ter-kan yang diikuti preposisi dan disertai Pel. Berikut ini disajikan beberapa contoh kalimat yang terkait dengan bentuk Vbaf ter- atau ter-kan tersebut.

(43) Gelar scudetto tergantung pada Roma.

(44) Setiap bab terbagi menjadi subbab. 
(45) Karya sastra terbedakan dari aneka objek yang membawa orang kepada yang universal.

Preposisi pada setelah verba tergantung pada kalimat (43) dan preposisi menjadi setelah verba terbagi pada kalimat (44) bersifat tidak wajib. Artinya, preposisi setelah verba tersebut dapat ditiadakan yang digambarkan dengan lambang dalam struktur kalimat, sedangkan preposisi dari setelah verba terbedakan pada kalimat (45) bersifat wajib (tidak dapat ditiadakan) yang digambarkan dalam struktur kalimat dengan lambang * . Di samping itu, preposisi setelah verba pada kalimat (43-45) di atas masing-masing dapat divariasikan dengan preposisi lain yang relevan. Hal tersebut dapat digambarkan dalam struktur kalimat (43a-45a) berikut.

(43a) Gelar scudetto tergantung $\left\{\begin{array}{c}\text { kepada } \\ \text { pada } \\ \text { dari } \\ \theta\end{array}\right\}$ Roma.
(44a) Setiap bab terbagi_ $\left\{\begin{array}{c}\text { atas } \\ \frac{\text { menjadi }}{* \text { dari }} \\ \theta\end{array}\right\}$ subbab.
(45a) Karya sastra terbedakan_ $\left\{\begin{array}{c}\text { dengan } \\ \frac{\text { dari }}{* \theta}\end{array}\right\}$ aneka objek

\section{Bentuk Preposisi yang Menyertai Verba}

Dalam bahasa Indonesia bentuk preposisi dapat berupa kata tunggal dan kata gabungan (lihat: Alwi et al., 1998). Quirk at. al. (1989) menyebutnya bentuk preposisi sederhana dan preposisi kompleks. Sementara itu, Kridalaksana et al. (1985) dan Kridalaksana (1986) menyebutkan bentuk preposisi itu berupa kata dasar (kata tanafiks) dan 
kata turunan (kata berafiks dan kata gabungan). Substansi pada ketiga pandangan tersebut hampir sama. Oleh karena itu, dalam tulisan ini hanya digunakan salah satu pandangan tersebut, yakni konsep yang dikemukakan oleh Alwi et al (1998) bahwa preposisi dikelompokkan atas dua golongan, yaitu preposisi yang berupa kata tunggal dan preposisi yang berupa kata gabungan. Dua bentuk preposisi inilah yang akan dibicarakan lebih lanjut pada subbagian berikut.

\section{a. Preposisi Berbentuk Kata Thnggal}

Preposisi yang berupa kata tunggal ini dapat berbentuk kata dasar (kata tanafiks), misalnya di, ke, dari, pada, atas, akan, untuk, buat, dengan, antara dan preposisi berupa kata berafiks, misalnya terhadap, bagaikan, menjadi. Berikut ini, contoh kalimat dengan bentuk verba + preposisi yang berupa kata tunggal.

(46) Tampaknya, peneliti tidak tahu akan kelemahan teori yang digunakan.

(47) Penjualan mobil dan komputer bergantung pada kualitas barang tersebut.

(48) Hubungan P-Pel dibagi atas hubungan struktural wajib dan tidak wajib.

(49) Semua pihak bertanggung jawab terhadap pelaksanaan kegiatan.

(50) Secara geografis bahasa Bali dibedakan menjadi bahasa Bali Aga dan bahasa Bali Daratan.

Preposisi akan setelah verba tahu pada kalimat (46), preposisi pada setelah verba bergantung pada kalimat (47), dan preposisi atas setelah verba dibagi pada kalimat (48) tersebut masing-masing adalah preposisi tunggal tanafiks, sedangkan preposisi terhadap setelah verba bertindak pada kalimat (49), dan preposisi menjadi setelah verba dibedakan pada kalimat (50) masing-masing merupakan bentuk preposisi tunggal berafiks. Penggunaan setiap preposisi tersebut dapat divariasikan dengan preposisi lain yang relevan, bahkan dapat pula divariasikan 
dengan ketidakhadiran preposisi tersebut setelah verba. Hal yang terakhir ini bergantung pada keterikatan hubungan semantis antara verba dan preposisi yang menyertainya. Altematif variasi penggunaan preposisi setelah verba pada kalimat (46-50) di atas dapat digambarkan dalam struktur kalimat (46a-50a) berikut.

(46a) Tampaknya, peneliti tidak tahu

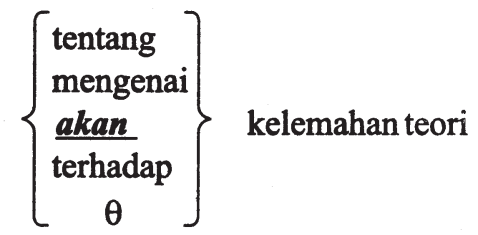
yang digunakan.

(47a) Penjualan mobil dan komputer bergantung $\left\{\begin{array}{l}\text { terhadap } \\ \text { kepada } \\ \text { pada } \\ \text { dari } \\ \theta\end{array}\right\}$ kualitas barang tersebut.

(48a) Hubungan P-Pel dibagi $\left\{\begin{array}{l}\text { menjadi } \\ \frac{\text { atas }}{\text { jadi }} \\ \theta\end{array}\right\}$ hubungan struktural wajib

dan tidak wajib. $\left\{\begin{array}{c}\text { pada } \\ \text { (49a) Semua pihak bertanggung jawab } \\ \theta\end{array}\right\}$ pelaksanaan kegiatan.

(50a) Secara geografis bahasa Bali dibedakan $\left\{\begin{array}{c}\text { atas } \\ \text { menjadi } \\ \text { jadi }\end{array}\right\}$ bahasa Bali Aga dan bahasa Bali Daratan.

Preposisi setelah verba pada struktur kalimat (46a-50a) masingmasing dapat ditiadakan atau dielipskan dan kalimat yang dihasilkannya tetap berterima, Oleh sebab itu, struktur kalimat (46b-50b) berikut tetap berterima. 
(46b) Tampaknya, peneliti tidak tahu $\theta$ kelemahan teori yang digunakan.

(47b) Penjualan mobil dan komputer bergantung $\theta$ kualitas barang tersebut.

(48b) Hubungan P-Pel dibagi $\theta$ hubungan struktural wajib dan tidak wajib.

(49b) Semua pihak bertanggung jawab $\theta$ pelaksanaan kegiatan.

(50b) Secara geografis bahasa Bali dibedakan $\theta$ bahasa Bali Aga dan bahasa Bali Daratan.

Apabila di antara verba dan preposisi pada kalimat (46-50) di atas disisipkan fungsi sintaksis lain, misalnya $\mathrm{K}$, preposisi-preposisi tersebut menjadi wajib hadir (yang diberikan tanda *), kecuali preposisi pada kalimat (46) berkemungkinan tidak dihadirkan (yang diberi tanda) karena antara verba tahu dan preposisi akan tidak memiliki keterikatan semantis. Hal tersebut dapat ditunjukkan dalam struktur kalimat (46c $-50 c)$ berikut.

(46c) Tampaknya, peneliti tidak tahu secara jelas

$\mathrm{K}$

kelemahan teori yang digunakan.

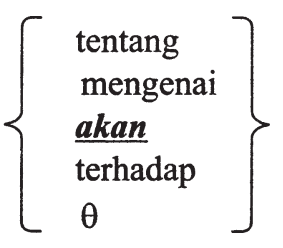

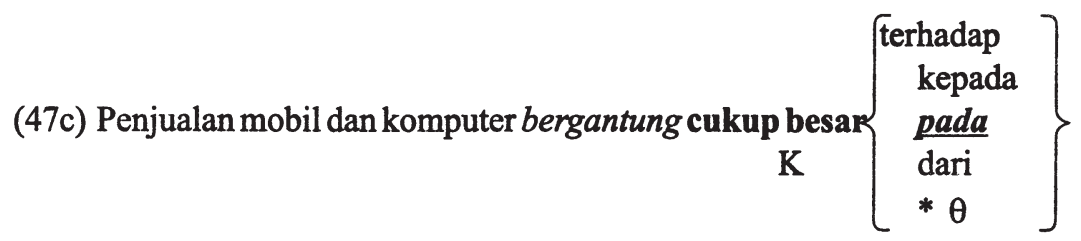
kualitas barang tersebut. 


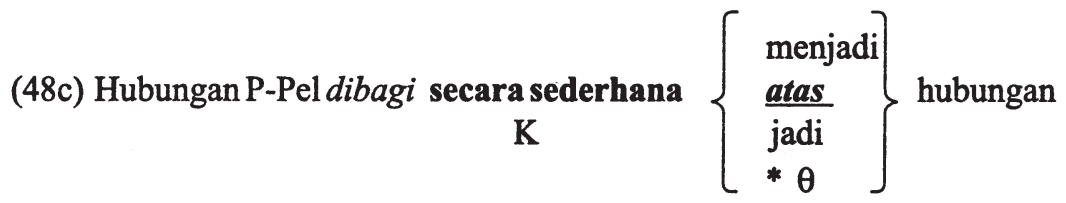
struktural wajib dan tidak wajib.

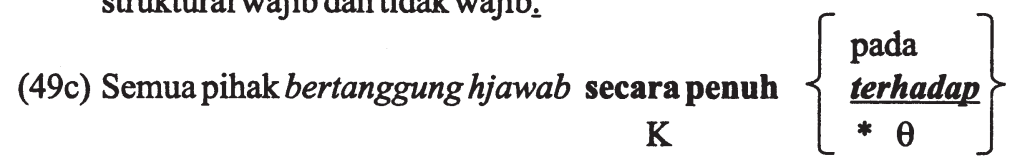
pelaksanaan kegiatan.

(50c) Secara geografis bahasa Bali dibedakan secara tegas $\underset{\mathrm{K}}{\text { menjadi }}\left\{\begin{array}{l}\text { atas } \\ \text { jadi } \\ * 0\end{array}\right\}$ bahasa Bali Aga dan bahasa Bali Daratan.

\section{b. Preposisi Berbentuk Kata Gabungan}

Secara teoretis, preposisi yang berupa kata gabungan ini ada dua, yaitu kata gabungan berdampingan, seperti kepada, ke dalam, di dalam, daripada, oleh karena, dan kata gabungan berpasangan, seperti antara dan dari hingga dari sampai (lihat: Kridalaksana at. al., 1985; Kridalaksana, 1986; dan Alwi at. al., 1998). Berikut ini disajikan beberapa contoh kalimat yang mengandung preposisi gabungan setelah verba, khususnya yang disertai Pel.

(51) Pengetahuan ini berorientasi kepada pengalaman pribadi.

(52) Baik bahasa maupun lagu Indonesia termasuk ke dalam seni ekspresi,

(51) Nilai nitrat berkisar antara 0 sampai $11,30 \mathrm{mg} \mathrm{L-1.}$

Preposisi gabungan berdampingan kepada setelah verba berorientasi pada kalimat (51) bersifat wajib hadir, terutama dalam ragam tulis formal, sedangkan preposisi ke dalam setelah verba termasuk pada kalimat (52) bersifat tidak wajib sehingga berkemungkinan dielipskan. Penggunaan kedua preposisi tersebut dapat divariasikan dengan preposisi 
lain yang relevan. Misalnya, preposisi kepada pada kalimat (51) dapat divariasikan dengan kata pada, ke atau terhadap, sedangkan preposisi ke dalam pada kalimat (52) dapat divariasikan dengan kata ke, pada, dalam, atau dengan pengelipsan preposisi. Demikian pula preposisi gabungan berpasangan antara...sampai... setelah verba berkisar pada kalimat (53) dapat divariasikan dengan preposisi antara...hingga..., antara...dan..., dari...sampai..., dari...hingga..., sementara itu, kata antara setelah verba berkisar pada kalimat (53) tersebut dapat ditiadakan dan kata sampai dapat disubstitusi dengan tanda pisah (--) yang bermakna 'sampai'. Hal-hal tersebut dapat ditunjukkan dalam struktur kalimat (51 a-53a) berikut.

(51a) Pengetahuan ini berorientasi $\left\{\begin{array}{l}\text { pada } \\ \text { ke } \\ \text { kepada } \\ \text { terhadap } \\ * 0\end{array}\right\}$ pengalaman pribadi.
(52a) Baik bahasa maupun lagu Indonesia termasuk $\left\{\begin{array}{l}\text { dalam } \\ \frac{\text { kedalam }}{\text { pada }} \\ 0\end{array}\right\}$ seni ekspresi.

(53a) Nilai nitrat berkisar $\left\{\begin{array}{l}\text { antara } \\ \text { antara } \\ \text { dari } \\ \frac{\text { antara }}{\text { dari }} \\ \text { dari } \\ 0\end{array}\right\} \quad \underline{0}\left\{\begin{array}{l}\text { dan } \\ \text { hingga } \\ \text { sampai } \\ \text { sampai } \\ \text { sampai } \\ -- \\ --\end{array}\right\} \quad 11,30 \mathrm{mg} \mathrm{L}-1$.

Apabila setelah verba pada kalimat (51-53) di atas disisipkan fungsi sintaksis $\mathrm{K}$ atau yang lain, preposisi yang menyertai verba tersebut wajib hadir setelah K atau sebelum Pel. Ketidakhadiran preposisi tersebut setelah K atau sebelum Pel akan berakibat pada kalimat yang dihasilkannya meragukan atau tak berterima, khususnya secara sintaktis. 


\section{Simpulan}

Verba berpreposisi (VBp) merupakan bentuk verba yang diikuti preposisi. VBp tersebut terdiri atas unsur verba dan preposisi yang masing-masing tidak menjadi unsur pokok atau tambahan, tetapi merupakan poros (aksis) dan direktor. Oleh sebab itu, verba berpreposisi bersifat eksosentris direktif.

Bentuk verba yang diikuti preposisi dapat berupa verba dasar (verba yang belum mengalami proses morfologis) dan verba turunan (verba yang telah mengalami proses morfologis, terutama afiksasi). Afiksafiks yang biasa digunakan pada bentuk VBp, antara lain ber-, ber-an, ber-kan (misalnya, berfungsi sebagai, berkenaan dengan, berdasarkan atas); di-, di-kan, di-i, diper-kan (misalnya, dibagi atas, diarahkan kepada, diikuti oleh, dipergunakan sebagai); me(N)- (misalnya, mengarah pada, mengacu ke); ter-, ter-kan (misalnya, tergantung pada, terdiri atas, terbedakan dari). Sementara itu, bentuk preposisi pada VBp dapat berupa preposisi tanafiks (misalnya, di, ke, dari, pada, atas, dengan), preposisi berafiks (misalnya, sebagai, terhadap, menjadi, mengenai), dan preposisi gabungan, baik gabungan berdampingan (misalnya, kepada, daripada, ke dalam, di dalam) maupun gabungan berpasangan (misalnya, antara... dan...; antara...dengan...; dari... hingga...). Di samping itu, kehadiran preposisi setelah verba ada yang bersifat wajib (misalnya, berkembang menjadi, berdomisili di, berkenaan dengan) dan ada yang bersifat tidak wajib (misalnya, berbicara tentang, dihadiri oleh, terdiri atas/dari).

\section{DAFTAR PUSTAKA}

Alwi, Hasan.1992. Modalitas dalam Bahasa Indonesia. Yogyakarta: Kanisius.

Alwi, Hasan et al. 1998. Tata Bahasa Baku Bahasa Indonesia, (Edisi III). Jakarta: Balai Pustaka.

Coe, Norman. 1981. A Learner's Grammar of English. Canada: Nelson, Ltd. 
Cook, Walter A., S.J. 1979. Case Grammar: Development of the Matrix Model (1970-1978). Washington, D.C: Georgetown University Press.

Downing, Angela dan Philip Locke. 1992. A University Course in English Grammar. Great Britain: Prentice Hall International, Ltd.

Kridalaksana, Harimurti. 1986. Kelas Kata dalam Bahasa Indonesia. Jakarta: Gramedia.

Kridalaksana, Harimurti, et al. 1985. Tata Bahasa Deskriptif Bahasa Indonesia: Sintaksis. Jakarta: Pusat Pembinaan dan Pengembangan Bahasa, Depdikbud.

Leech, Geoffrey dan Jan Svartvik.1987. A Communicative Grammar of English. Singapore: Longman Singapore Publishers (Pte.). Ltd. Murphy, Raymond. 1987. English Grammar in Use. Cambridge: Cambridge University Press.

Noonan, Michael. 1994. "Complementation”, dalam Language Typology and Syntactic Description: Complex Constructions. Shopen, Timothy (Ed.). Newcastle: Athenaeum Press, Ltd.

Quirk, Randolph, et al. 1989. A Grammar of Contemporary English. Hong Kong: Longman Group, Ltd.

Ramlan, M. 1980. Kata Depan atau Preposisi dalam Bahasa Indonesia, Cetekan I., Yogyakarta: U.P. Karyono. , 1996. Ilmu Bahasa Indonesia: Sintaksis. Yogyakarta: C.V. Karyono.

Sugono, Dendy dan Titik Indiyastini.1994. Verba dan Komplementasinya. Jakarta: Pusat Pembinaan dan Pengembangan Bahasa, Depdikbud.

Thomas, Linda. 1993. Beginning Syntax. Great Britain: T.J. Press, Ltd. Thomson, A.J. dan Martinet, A.V. 1987. A Practical English Grammar. Oxford: Oxford University Press.

Verhaar, J.W.M. 1979. Pengantar Linguistik I. Yogyakarta: Gadjah Mada University Press.

Wojowasito, S. 1970. Ilmu Kalimat Strukturil. Bandung: Shinta Dharma. 